\title{
Microscopic Findings Category
}

National Cancer Institute

\section{Source}

National Cancer Institute. Microscopic Findings Category. NCI Thesaurus. Code 1117580.

A classification of microscopic findings data. 